\title{
POWER SUPPLY SYSTEM FOR THE HELIUM IONS LINAC'S INJECTOR
}

\author{
R.A. Anokhin, S.N. Dubnyuk, N.I. Gaponenko, V.G. Zhuravlyov, A.V. Zhuravlyov, \\ A.V. Zabotin, B.V. Zajtsev, A.I. Kravchenko, A.F. Kobets, O.V. Manuilenko, \\ V.N. Reshetnikov, V.G. Svichenskiy, V.A. Soshenko, A.C. Shevchenko \\ National Science Center “Kharkov Institute of Physics and Technology”, Kharkiv, Ukraine
}

This paper presents compact power supply system for the helium ion linac's injector. The system consists of high-voltage modulator, power supplies of cathode filament, solenoid and arc modulator. It is designed on modern semi-conductor base. Using of the designed power supply system allowed to decrease the power consumption and to get rid of spurious capacitances and pickups. As a result of improving the continuous adjustment modulator and high-voltage pulse stabilization scheme, the accelerated beam current has increased twice.

PACS: 29.17.+w

\section{INTRODUCTION}

One of the basic blocks of the helium ion accelerators is the injector which provides getting required particles and injects them into the accelerating space. Functioning of the injector requires cooperation of pulse and analog devices forming the injector power system, that consists mainly of power supplies and pulse modulators, the output voltage range of which is from tens of volts to hundreds of kilovolts.

The injector's power system consists of: filament power supply $(\sim 1 \mathrm{~kW})$; power supply of the focusing magnet system with output current up to $5 \mathrm{~A}$ and $15 \mathrm{~V}$ voltage, modulator of the arc and modulator of the injector. The arc modulator must give the pulse with about $200 \mathrm{~V}$ amplitude and up to $800 \mathrm{~V}$ overshoot and up to 1.5 A current. As for injector modulator, it's required to get the $130 \mathrm{kV}$ (on the $400 \mathrm{kOhm}$ load) amplitude that must be linear control. On this understanding, severe requirements are imposed to the peak of the pulse [1,2]. The specialty of such construction of the injector is the direct coupling of all the power supplies with the high voltage $(140 \mathrm{kV})$. So, all the power supplies (except high voltage modulator) are placed in the isolated screened corona shield cover (CSC), which isolates them from power feeders by decoupling transformers. Both the CSC and the decoupling transformers sit the hundreds of kilovolts isolation. Such construction of the accelerators' injectors' power systems is traditional and has been used for the several decennaries. The sizes of CSCs reach tens of cubic meters, that is defined firstly by sizes of the used power supplies and by their element base.

\section{MODERNIZATION \\ OF THE ACCELERATOR'S INJECTOR POWER SYSTEM}

In the Fig. 1 there is the block-scheme of the traditional power system for the particle accelerator injector, which is feed from the power feeder with the $50 \mathrm{~Hz}$ frequency. This defines the dimensions of transformers used in the all of the system's blocks. Forasmuch as all the power system's components are under high voltage, the decoupling transformer is used. Its dimensions sharply increase because it's necessary to provide the electric strength.
The lack of this power system is spurious capacitance which has two components. First component is defined by CSC's ground capacitance, and second is defined by capacitance of power transformers and pulse transformers placed inside the CSC. Both of the components have commensurable values. The CSC's spurious capacitance decreases the modulator's efficiency by increasing the fronts of the output pulse. The capacitance of our CSC is $1000 \mathrm{pF}$. When the operating voltage is $130 \mathrm{kV}$, system consumes energy of 8.5 joules, that overtops $30 \%$ of operating pulse energy on the load.

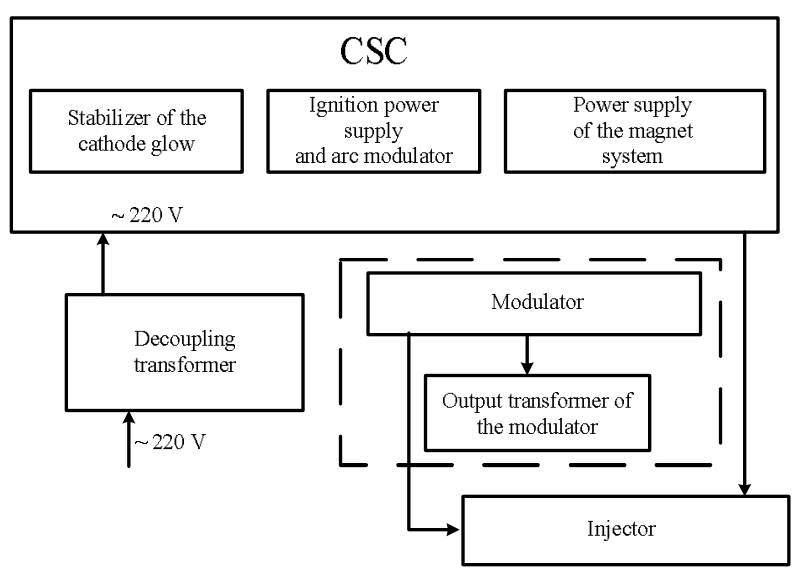

Fig. 1. The block scheme of the accelerator's power system

The current construction of the system is based on electronic tubes, because the disposable semi-conductor base doesn't have high-current and high-voltage elements. So the main used elements were thyratrons, that were widely used for high voltages rectification and for commutation. The energy consumed by their filaments, also greatly decreases the injector power system's efficiency.

On the strength of the modern semi-conductor element base development, the necessity of designing the new injector power system which will allow to get rid of the above-mentioned lacks is quite obvious.

The aim of this work is rising of the injector power system efficiency. The methods we used are given below.

To eliminate the above-mentioned lacks we have developed the injector power system block scheme of which is shown in the Fig. 2. It will be observed that construction principles and technology used in this scheme can be useful in making similar systems of accelerating and high-voltage equipment. Unlike the 
scheme shown in the Fig. 1, this one doesn't have the decoupling transformer of the power feeder. It has allowed to get rid of the CSC and, accordingly, of the spurious capacitances that lead to lowering of the efficiency.

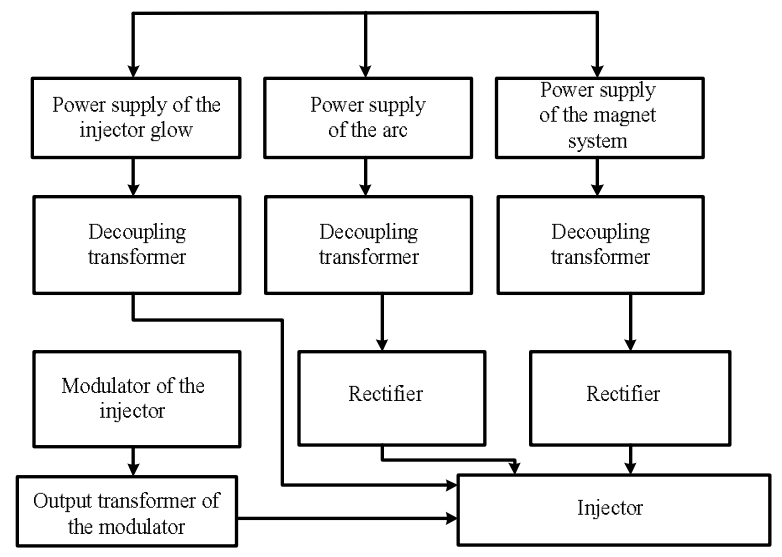

Fig. 2. The block scheme of the injector's power supply system

It's known that the voltage frequency defines the main dimensions of transformers, so to decrease the weight and dimensions in airplane making there is used a $400 \mathrm{~Hz}$ frequency in airborne circuits. The modern semi-conductor converter technology allows making power supplies with high conversion frequencies (hundreds of kilohertz). So the $80 \mathrm{kHz}$ conversion frequency that we've chosen in our power system is a tradeoff that allows great lightening of the transformers' dimensions and weight and reducing of the measurement circuits' pickup level. There isn't any decoupling power highvoltage transformer in this power system. Instead of it there are used three high-frequency decoupling transformers-converters.

The decoupling transformers are based on the Oshaped ferrite cores. To provide electric strength of the transformers, we have developed the special construction of the polymethyl-acrylic bobbin, where the possibility of electrical surface breakdown between the coil and the core is eliminated. The transformer is placed in the transformer oil. Small size of the transformers and the common high-voltage potential has allowed placing the transformers in the united dielectric case $(310 \times 230 \times 290 \mathrm{~mm}$ size). The main feature of transformer's construction is twice oversized core. The voltage breakdown tests carried with using the $150 \mathrm{kV}$ voltage had shown neither surface flashovers nor internal ones.

The filament power supply $(40 \mathrm{~A}, 25 \mathrm{~V})$ is one of the most energy-intensive blocks. It is based on the bridge-type voltage converter, with $80 \mathrm{kHz}$ conversion frequency. The elements the bridge is based on are the IGBT-structures. While developing this converter we tested two constructions of it. It was discovered that using the bridge in the switching mode was inexpedient, even with the active resistance load $(0.5 \mathrm{Ohm})$. The reason is the induction of voltage in the primary coil of the bridge converter's transformer when the semi-bridge is disconnected; it's contributed by the speed of transistor closing and high commutation currents. The amplitude of this voltage is commensurable with power voltage; this causes failures in the bridge's control scheme, the growing of extra dissipation on the transistor's integral diode and, as a result, the mortality of this diode.

To eliminate the reason of the pickups, the bridge's operating mode is changed from switch one to resonance one. In this mode, the bridge's transistors switch when the transformer's current is crossing zero. It eliminates the capability of voltage induction.

The availability of the decoupling transformers doesn't allow using the pulse-width modulation for output voltage adjustment. So the converter's output voltage is adjusted by changing the power voltage on the transistors' drains. For this, the adjustable pulse stabilizer [3] with $0 \ldots 310 \mathrm{~V}$ adjustment range has been designed. The main advantage of this stabilizer is the high efficiency that makes possible to reduce control transistor dissipation and to provide wide dynamic range of output voltages and low pickup level. The results of prototyping have shown that the stabilizer with pulsewidth modulation and fixed switching frequency $(\sim 10 \mathrm{kHz})$ is the most suitable for these purposes. It will be observed that the stabilizer is operable when the dissipation on the load is up to $5 \mathrm{~kW}$.

The power supplies of the magnet system and arc are also the inverters with $\sim 80 \mathrm{kHz}$ conversion frequency. But their low output power level allows using the linear controllers. Such an approach lets place the power supplies closely to the injector.

During the previous modernizations of the injector's power systems, the thyristor-based modulator was made. This modulator uses the dual shaping line made of the LC links. The advantage of the dual line towards the single one is the lower charging voltage that permits fourfold reducing of the energy needed to recharge the spurious capacitances. The lack of using LC links is the ripple of the formed pulse's flat part because of oscillations. This ripple increases the variation of ions' speeds in the formed accelerated beam and lowers the efficiency of accelerating. To get rid of this lack, the modulation pulse peak stabilizing device has been designed. It consists of the parallel stabilizer (based on fast voltage suppressors) and controlled high-voltage rectifier which allows adjusting the output pulse at the range $\pm 5 \mathrm{kV}$.

The results of the measurement have shown that pulse instability isn't higher than $0.5 \%$. Placing the diodes in the transformer oil lets provide the long-time voltage stability, lower heat load of the diodes and higher electrical strength of the device. In the Fig. 3 the oscillograms of non-stabilized (a) and stabilized (b) injector voltage $(120 \mathrm{kV})$ are shown. It can be seen that there aren't any traces of the LC links oscillations at the flat part of the pulse. It will be observed that the tests of the amplitude stabilizer have shown that the accelerated beam current has increased twice.

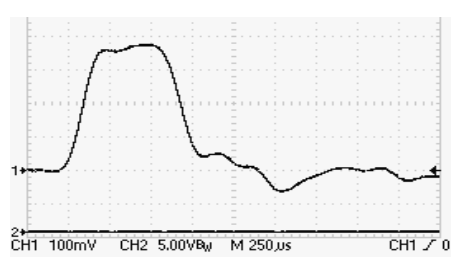

a

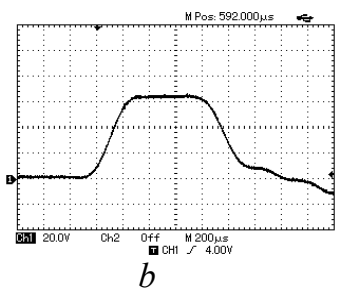

$b$
Fig. 3. Injector power voltage: non-stabilized (a); stabilized (b) 
One of the main lacks of the shaping circuits based on LC-links is the principal impossibility of output pulse length smooth adjustment. Such a construction of modulator was caused by element base that included only thyratrons and thyristors. The development of high-voltage field effect and compatible controlled semi-conductor structures where switched current is up to several kilo amperes and permissible voltage is up to several kilovolts lets us form the modulating pulse with variable length. We have designed and been testing the modulator which consists of modulator driver and highvoltage switch loaded by the output transformer. As the modulator driver, the synchronized pulse generator with controlled pulse length is used.

Its mode of functioning is based on charging the capacitor with the stable current after the arrival of the synchronizing pulse. The main advantages of such decision are high jamming protection and output signal stability in the intensive pulse jamming conditions, simple realizing of remote control of the output pulse length.

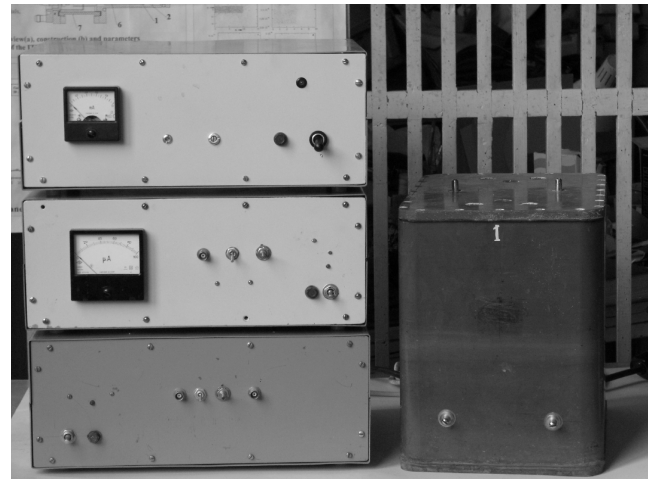

Fig. 4. Power supplies and box decoupling transformers

The output switch of the modulator is based on 10 high-voltage IGBT transistors connected in cascode mode. It has permitted commutation of voltages up to $11 \mathrm{kV}$ and 24 A currents. The collector voltages equali- zation and overvoltage protection is provided by the fast voltage suppressors with voltage limitation on the transistors' gates. The reliable work of the switch is achieved by choosing the transistors' operating point offset and matching the parameters of equalizing circuits in the transistors' gates.

In the Fig. 4 the power supplies units and the decoupling transformers are shown.

\section{CONCLUSIONS}

We have designed and implemented the power system for the helium ion linac's injector. The system is fully based on the semi-conductor elements.

The system has small size. This permitted getting rid of the corona shield cover and decreasing of the injector's modulator load.

As a result of embedding the pulse power stabilization system, the accelerating beam current has increased twice.

The results of the tests have shown high reliability of the system and high resistance to the voltage breakdowns.

\section{REFERENCES}

1. B.P. Murin, V.G. Kulman, L.G. Lomidze, et al. Linear ion accelerators (in 2 volumes): The main systems / Edited by B.P. Murin. M.: “Atomizdat", 1978, $320 \mathrm{p}$.

2. O.V. Yelsukov et al. Questions of the atomic science and technology // $6^{\text {th }}$ ISSUE. Series "Nuclear physical researches (theory and experiments)". 1989, p. 19-22.

3. I.M. Gotlib. Power supplies. Inverters, converters, linear and pulse stabilizers. M.: "Postmarket", 2002, p. 544.

Article received 22.01.2020

\section{СИСТЕМА ПИТАНИЯ ИНЖЕКТОРА ЛИНЕЙНОГО УСКОРИТЕЛЯ ИОНОВ ГЕЛИЯ}

\section{Р.А. Анохин, С.Н. Дубнюк, Н.И. Гапоненко, В.Г. Журавлев, А.В. Журавлев, А.В. Заботин, Б.В. Зайцев, А.И. Кравченко, А.Ф. Кобец, О.В. Мануйленко, В.Н. Решетников, В.Г. Свиченский, В.А. Соченко, А.С. Шевченко}

Приведены принципы построения и описание малогабаритной системы питания инжектора линейного ускорителя ионов гелия, состоящей из высоковольтного модулятора, блоков питания накала катода, соленоида и модулятора дуги, выполненных на современной полупроводниковой элементной базе. Применение разработанной системы питания позволило существенно снизить энергозатраты, избавиться от паразитных емкостей и наводок. Стабилизация амплитуды импульса высокого напряжения позволила увеличить ток ускоренного пучка в 2 раза.

\section{СИСТЕМА ЖИВЛЕННЯ ІНЖЕКТОРА ЛІНІЙНОГО ПРИСКОРЮВАЧА ІОНІВ ГЕЛІЮ}

\section{Р.О. Анохин, С.М. Дубнюк, М.І. Гапоненко, В.Г. Журавльов, А.В. Журавльов, О.В. Заботін, Б.В. Зайцев, А.І. Кравченко, А.П. Кобець, О.В. Мануйленко, В.М. Решетников, В.Г. Свіченський, В.А. Соченко, О.С. Шевченко}

Наведено опис малогабаритної системи живлення інжектора лінійного прискорювача іонів гелію, яка складається з високовольтного модулятора, блоків живлення накалу катода, соленоїда та модулятора дуги. Система виконана з використанням сучасної напівпровідникової елементної бази. Застосування розробленої системи живлення дозволило суттєво знизити енерговитрати, позбавитися паразитних ємностей та наведень. У результаті впровадження схеми стабілізації імпульсу високої напруги струм прискореного пучка збільшився в 2 рази. 